\title{
Pengaruh Pemanasan Terhadap Kemampuan Tanah Diatomit Sebagai Adsorben Logam Krom (III) dan Kadmium (II)
}

\author{
Nuryono, Eko Sri Kunarti, Narsito
}

Jurusan Kimia, FMIPA UGM, Sekip Utara, Yogyakarta 55281

\begin{abstract}
Abstrak
Telah dilakukan penelitian untuk mengkaji pengaruh pemanasan terhadap kemampuan tanah diatomit Sangiran, Sragen, Jawa Tengah terhadap kemampuannya mengadsorbsi logam Cr(III) dan Cd(II) dalam larutan. Sebelum proses adsorpsi dilakukan tanah diatomit dikarakterisasi keberadaan situs aktifnya dengan menggunakan spektrofotometri infra merah (IR) dan analisis termogravimetri (TGA). Adsorpsi dilakukan melalui sistem bath dengan mencampurkan sejumlah sampel tanah dengan larutan logam pada temperatur kamar, $30^{\circ} \mathrm{C}, \mathrm{pH} \mathrm{4,0}-6,0$ (tanpa pengaturan) untuk $\mathrm{Cr}(\mathrm{III})$, dan $5.0-7,0$ untuk $\mathrm{Cd}$ (II). Proses serupa dilakukan terhadap tanah diatomit yang telah dipanaskan pada temeperatur yang berbeda $\left(300^{\circ} \mathrm{C}, 500^{\circ} \mathrm{C}\right.$ dan $\left.900^{\circ} \mathrm{C}\right)$. Pengaruh lama kontak dan konsentrasi awal logam terhadap adsorpsi dievaluasi untuk menentukan kapasitas, tetapan adsorpsi, dan energi adorpsi. Hasil penelitian menunjukkan bahwa tanah diatomit melepaskan semua molekul air pada pemanasan $580^{\circ} \mathrm{C}$, dan kondensasi gugus silanol menjadi siloksan terjadi pada pemanasan $700^{\circ} \mathrm{C}$. Pemanasan tanah diatomit sampai $500^{\circ} \mathrm{C}$ dapat meningkatkan kemampuan mengadsorpsi ion $\mathrm{Cr}(\mathrm{III})$, sedangkan untuk adsorpsi ion $\mathrm{Cd}$ (II) tidak berubah secara signifikan. Sebaliknya, pemanasan sampai $900^{\circ} \mathrm{C}$ mengaikbatkan penurunan yang tajam terhadap kemampuannya mengadsorpsi baik ion $\mathrm{Cr}$ (III) maupun $\mathrm{Cd}(\mathrm{II})$. Kapasitas adsorpsi tertinggi untuk $\mathrm{Cr}$ (III), $205,3 \mathrm{mg} / \mathrm{g}$, terjadi pada tanah setelah pemanasan $500^{\circ} \mathrm{C}$, sedangkan untuk $\mathrm{Cd}(\mathrm{II}), 14.93 \mathrm{mg} / \mathrm{g}$, terjadi pada tanah setelah pemanasan $300^{\circ} \mathrm{C}$. Tetapan adsorpsi berkisar $6.93-11,51 \times 10^{3}$ untuk Cd(II) dan $0,94-1,58 \times 10^{3}$ untuk $\mathrm{Cr}$ (III), sedangkan energi adsorpsi berkisar $17,30-18,55 \mathrm{~kJ} / \mathrm{mol}$ untuk $\mathrm{Cr}(\mathrm{III})$ dan $21,49-23,56 \mathrm{~kJ} / \mathrm{mol}$ untuk $\mathrm{Cd}(\mathrm{II})$.
\end{abstract}

Kata kunci : Tanah diatomit, adsorben, Krom (III), Kadmiun (II), adsorpsi

\section{Effect of Heating on Capability of Diatomae Earth as Adsorbent for Chromium (III) and Cadmium (II)}

\begin{abstract}
A research to study the efeect of heating on diatomite earth of Sangiran, Sragen Central java in capability to adsorb $\mathrm{Cr}(\mathrm{III})$ and $\mathrm{Cd}(\mathrm{II})$ in aqueous has been cariied out. Prior to the adsorpstion process, functional groups of diatomite earth was characterized by using Infrared spectrophotmeter and thermal gravimetric analysis. Adsorption was carried out in a a bath system by mixing an amount of diatomite earth with solution of metal ion at room temperature $\left(30^{\circ} \mathrm{C}\right)$, $\mathrm{pH}$ of $4.0-6.0$ (without adjusment) for $\mathrm{Cr}(\mathrm{III})$, and of $5.0-7.0$ for $\mathrm{Cd}(\mathrm{II})$. Concentration of metal unadsorbed was determined by Adsorption Atomic Spectroscopic method. The similar process was carried out for diatomite earths heated in different temperature $\left(300^{\circ} \mathrm{C}, 500^{\circ} \mathrm{C}\right.$, and $900^{\circ} \mathrm{C}$ ). The efeect of contact time and initial concentration on adsorption was evaluated to determine capacity, constant, and energy of adsorption. Results show that diatomite earth releases all of water molecules at heating of $580^{\circ} \mathrm{C}$, and condensation of silanol groups to form silxane occurs at $700^{\circ} \mathrm{C}$. Heating of diatomite earth up to $500^{\circ} \mathrm{C}$ increases earth's
\end{abstract}


capability in adsorbing $\mathrm{Cr}$ (III). For $\mathrm{Cd}$ (II), however, heating up to $500^{\circ} \mathrm{C}$ does not change significantly. On the other hand, heating up to $900^{\circ} \mathrm{C}$ causes drastically decrease of earth's

Capability in adsorbing either $\mathrm{Cr}(\mathrm{III})$ or $\mathrm{Cd}(\mathrm{II})$. The highest adsorpstion capacity for $\mathrm{Cr}(\mathrm{III})$, $205.3 \mathrm{mg} / \mathrm{g}$, occurs on the diatomite earth heated at $500^{\circ} \mathrm{C}$, while for $\mathrm{Cd}(\mathrm{II}), 14.93 \mathrm{mg} / \mathrm{g}$. occurs at $300^{\circ} \mathrm{C}$. Adsorption constant is in the rage of $6.93-11.51 \times 10^{3}$ for $\mathrm{Cr}(\mathrm{III})$, and adsorption energy is $17.30-18.55 \mathrm{~kJ} /$ mole for $\mathrm{Cr}(\mathrm{HI})$ and $21.49-23.56 \mathrm{~kJ} /$ mole for $\mathrm{Cd}(\mathrm{II})$.

Key words : Diatomite erath, adsorbent, adsorption, Chromium(III), Cadmium(II).

Telah dipresentasikan dalam Seminar Nasional : Perkembangan Peneliti Wanita, di Jurusan Kimia, FMIPA UNDIP, Semarang, 27 April 2000.

\section{PENDAHULUAN}

Dengan berkembangnya penggunaan teknologi yang diiringi dengan meningkatnya industrialisasi maka pembuangan limbah industri dapat menjadi masalah serius bagi kelestarian lingkungan. Oleh karena itu, penanganan terhadap limbah, terutama yang mengandung logam beracun, perlu mendapat perhatian yang serius pula. Dalam rangka menjaga kualitas lingkungan, terutama lingkungan bebas logam, dua langkah penting yang harus dilakukan adalah pertama memonitor kandungan logam dalam lingkungan, terutama limbah cair, secara ketat, dan kedua menanganinya jika ternyata limbah tersebut telah tercemar logam. Permasalahan yang muncul selanjutnya adalah bagaimana cara yang efektif untuk menghilangkan logam dalam limbah sebelum masuk ke lingkungan.

Salah satu upaya yang telah dikaji dalam rangka menghilangkan logam antara lain mengadsorpsi logam dengan menggunakan berbagai jenis adsorben, seperti tanah tropis, gambut, dan silika. Semu dkk [1] mengkaji adsorpsi logam merkuri dengan menggunakan tanah tropis dan Saadi [2] dengan menggunakan gambut. Keduanya memanfaatkan keberadaan bahan organik dalam tanah dan gambut untuk berperan sebagai situs aktifnya.
Adsorpsi logam diduga terjadi melalui gugus fungsional seperti $\mathrm{COOH}$ dalam tanah dan asam humat atau sulfida organik dalam tanah gambut. Filho [11] telah mengkaji aplikasi tanah lempung yang telah dimodifikasi dengan 2merkaptobenzotiasol (MBT) untuk prekonsentrasi beberapa logam berat. Kemudian Mahdian [3] mengkaji adsorpsi logam transisi $\mathrm{Zn}(\mathrm{II}), \mathrm{Co}$ (II) dan $\mathrm{Ni}$ (II) pada tanah diatomit yang telah diaktifkan melalui pemanasan $550^{\circ} \mathrm{C}$.

Tanah diatomit adalah endapan kulit atau kerangka organisme yang mengandung silika seperti diatom atau ganggang bersel satu yang terakumulasi membentuk endapan di dasar laut, air tawar, danau atau payau. Dengan demikian, silika merupakan komponen utama dalam tanah diatomit, meskipun besarnya bervariasi, bergantung pada usia, tingkat kemurnian, dan tempat asalnya (air laut atau air tawar) [3]. Tanah diatomit mempunyai sifat-sifat khusus, yaitu berpori kecil dan ringan dengan berat jenis berkisar $0,45 \mathrm{~g} / \mathrm{cm}^{3}$ (untuk serbuk kering). Selain itu, tanah diatomit mempunyai daya serap air yang tinggi, dan tidak larut asam. Berdasarkan sifat-sifat itu mengakibatkan tanah diatomit dapat dimanfaatkan dalam berbagai hal, seperti sebagai panyaring, bahan 
pengisi, bahan isolasi, penggosok, arsorben, katalis, pendukung, dan lainlain [4]. Tanah diatomit mengandung dua situs adsorpsi, yaitu situs Van der Walls, dan situs ikatan hidrogen yang berasal dari gugus silanol dan siloksan. Berdasarkan sifat ini, Priatna [5] secara khusus mengkaji pemanfaatan tanah diatomit untuk mengadsorpi zat pewarna malachite green dan untuk pemurnian air nira tebu. Purwanto dan Narsito [6] telah mengimpregnasikan MBT pada tanah diatomit dan mengaplikasikannya untuk adsorpsi $\mathrm{Hg}$ (II). Interaksi antara gugus silanol dalam tanah diatomit dan MBT melibatkan interaksi dipol-dipol yang mudah rusak akibat pelarutan.

Dalam paper ini dilaporkan hasil penelitian tentang pengaruh pemanasan terhadap sifat tanah diatomit, terutama kemampuannya dalam mengadsorpsi logam $\mathrm{Cr}$ (III) dan Cd(II) di dalam larutan. Di samping itu, disajikan pula beberapa parameter termodinamika adsorpsi, seperti tetapan keseimbangan adsorpsi, kapasitas adsorpsi, dan energi adsorpsi.

\section{METODOLOGI PENELITIAN}

\section{Bahan}

Bahan-bahan yang digunakan dalam penelitian ini adalah tanah diatomit yang berasal dari Sangiran, Kabupaten Sragen, Jawa Tengah; Larutan standar Cr(III) dan Cd(II) 1000 ppm yang dibuat dengan melarutkan $\mathrm{CdCl}_{2}$ dan $\mathrm{CrCl}_{3} \cdot 6 \mathrm{H}_{2} \mathrm{O}$ (E Merck, Jerman) dalam aquades hasil detilasi Laboratorium Kimia Anorganik, FMIPA, UGM.

\section{Alat}

$$
\begin{aligned}
& \text { Pada penelitian ini, alat-alat } \\
& \text { yang digunakan adalah ayakan }
\end{aligned}
$$

berukuran 250 mesh; furnace (Nabertherm, Bremen, Jerman); set alat sentrifugasi (model 228 maks 3400 rpm, Fischer Scientific, USA); spektrofotometer serapan atom (Perkin Elmer 3110 , USA) untuk analisis logam dalam larutan; termogravimeter untuk alat analisis termogravimetri.

\section{Jalan Penelitian}

\section{Persiapan dan karakterisasi tanah diatomit.}

Tanah diatomit digerus dan diayak dengan ayakan ukuran 250 mesh. Hasil pengayakan selanjutnya dibagi menjadi empat bagian yang kemudian diperlakukan secara berbeda, yaitu 1 bagian tanpa pemanasan, 3 bagian lainnya dipanaskan masingmasing pada $300^{\circ} \mathrm{C}, 500^{\circ} \mathrm{C}$, dan $900^{\circ} \mathrm{C}$ selama 4 jam. Tanah diatomit kering, dikarakterisasi dengan analisis termogravimetri untuk mengetahui perubahan massa selama pemanasan, dan dengan spektrofotometri infra merah untuk mengkaji perubahan gugus fungsi yang ada pada tanah.

\section{Pengaruh Waktu pada Adsorpsi Logam pada Tanah Diatomit}

Sejumlah massa tertentu tanah diatomit, $25 \mathrm{mg}$ untuk adsorpsi $\mathrm{Cr}(\mathrm{III})$ dan $0,5 \mathrm{~g}$ untuk $\mathrm{Cd}(\mathrm{II})$, dimasukkan ke dalam botol, ditambahkan dengan 50 ml larutan logam dengan konsentrasi $30 \mathrm{ppm}$ untuk $\mathrm{Cr}$ (III) dan $50 \mathrm{ppm}$ untuk Cd (II). Kemudian diaduk dan disentrifius. Lama pengadukan dan sentrifius bervariasi, yaitu: $5^{\prime}, 10^{\prime}, 15^{\prime}$, $20^{\prime}, 25^{\prime}, 30^{\prime}, 1$ jam, 2 jam, dan 4 jam. Supernatan disaring dan konsentrasi logam dalam supernatan ditentukan dengan AAS. Logam yang teradsorpsi oleh tanah diatomit dihitung dari perbedaan antara jumlah logam mula- 
mula dan jumlah yang masih ada dalam larutan. Hal yang sama dilakukan terhadap tanah diatomit tanpa dipanaskan, dan yang telah dipanaskan pada suhu $300^{\circ} \mathrm{C}, 500^{\circ} \mathrm{C}$, dan $900^{\circ} \mathrm{C}$. Dari kurva hubungan antara jumlah logam yang teradsorpsi dengan lama kontak maka dapat ditentukan waktu yang diperlukan untuk mencapai keseimbangan

\section{Pengaruh Konsentrasi awal Logam pada Adsorpsi.}

Sejumlah massa tertentu tanah diatomit dimasukkan ke dalam botol, kemudian ditambahkan dengan $50 \mathrm{ml}$ larutan logam yang konsentrasinya diketahui. Konsentrasi logamyang digunakan dalam penelitian ini bervariasi dari $20,40,60,80,100,150$, $200,250,300$, dan 500 ppm. Selanjutnya dilakukan pengadukan selama 30 menit untuk Cr(III) dan 1 jam untuk $\mathrm{Cd}(\mathrm{II})$ agar tercapai keseimbangan. Supernatan disaring selanjutnya dianalisis dengan AAS. Jumlah logam yang teradsorpsi pada tanah diatomit dihitung dari selisih antara konsentrasi logam sebelum adsorpsi dan konsentrasi logam setelah adsorpsi mencapai keseimbangan. Hal yang sama dilakukan terhadap tanah diatomit yang telah dipanaskan pada suhu $300^{\circ} \mathrm{C}, 500^{\circ} \mathrm{C}$, dan $900^{\circ} \mathrm{C}$. Dari data jumlah logam teradsorpsi maka dapat dihitung kapasitas, tetapan keseimbangan, dan energi adsorpsi untuk setiap jenis tanah diatomit.

\section{HASIL DAN PEMBAHASAN}

\section{Pengaruh Pemanasan Terhadap} Karakter Tanah Diatomit

\begin{tabular}{lcr}
\multicolumn{1}{c}{ Hasil } & karakterisasi & tanah \\
diatomit & melalui & analisis \\
termogravimetri & disajikan & dalam \\
Gambar 1. & &
\end{tabular}

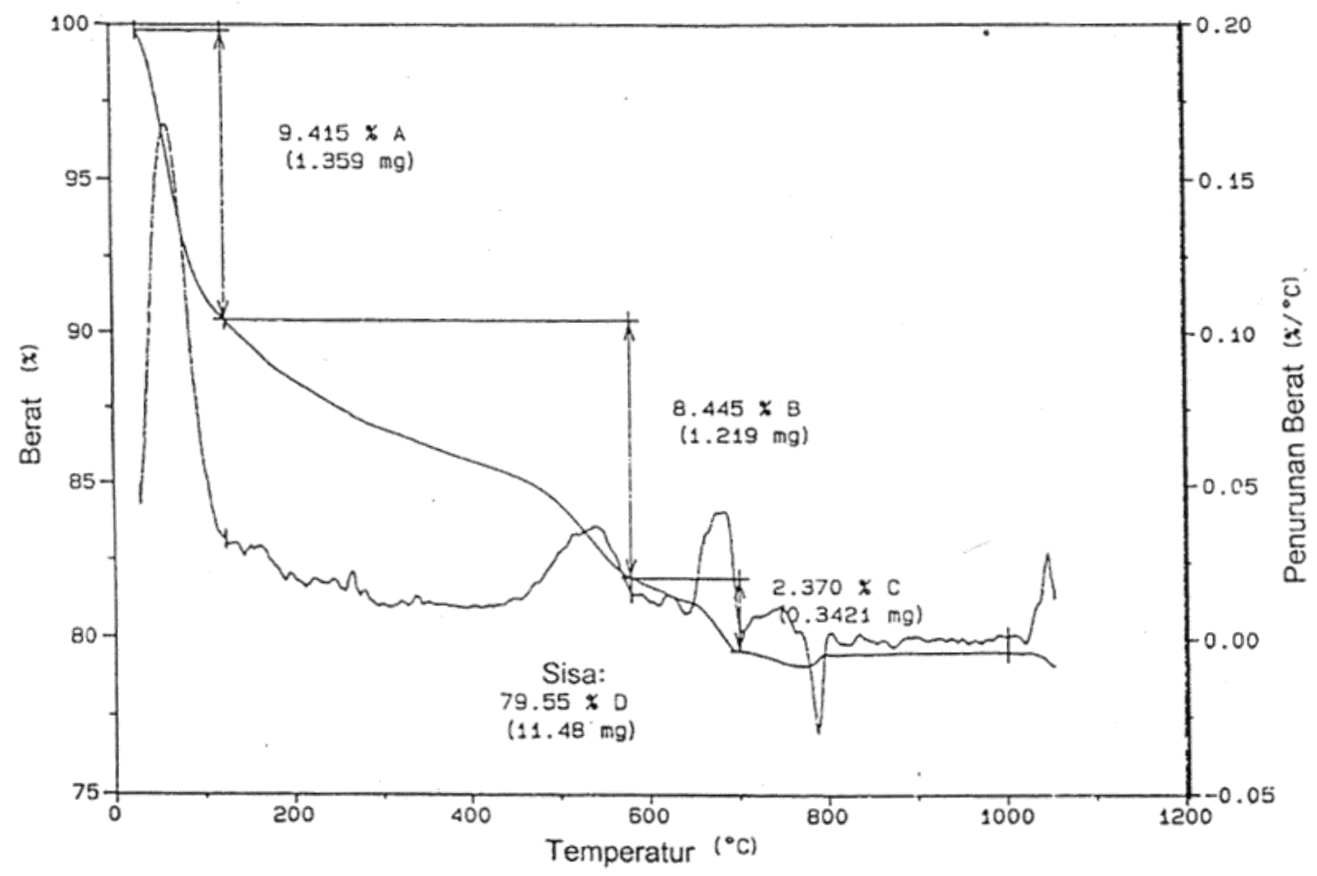

Gambar 1 Termogram TGA tanah diatomit 
Dari gambar tersebut terlihat bahwa ada tiga daerah temperatur yang menunjukkan terjadinya penurunan massa tanah, yaitu pada $20-120^{\circ} \mathrm{C}$, $120-580^{\circ} \mathrm{C}$, dan $580-700^{\circ} \mathrm{C}$.

Termogram tanah diatomit tersebut mirip dengan termogram silika gel yang dikemukakan oleh Scott [7]. Dalam termogram silika gel, ketiga daerah penurunan massa tersebut dapat dijelaskan melalui teori yang menyebutkan bahwa dalam silika gel terdapat tiga lapisan molekul air (Gambar 2).

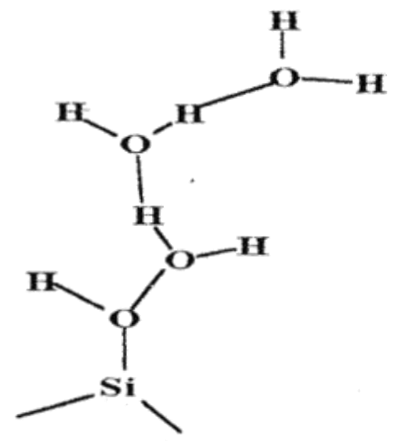

Gambar 2 Lapisan molekul air dalam silika gel

Pada daerah temperatur pertama terjadi pelepasan air yang terikat secara lemah pada lapisan pertama dan kedua dari tanah diatomit. Penurunan massa pada daerah temperatur kedua merupakan hasil dari pelepasan air pada lapisan pertama yang terikat relatif lebih kuat. Kemudian penurunan massa pada daerah ketiga $\left(580-700^{\circ} \mathrm{C}\right)$ merupakan hasil kondensasi gugus silanol dan menghasilkan siloksan. Hasil analisis ini menguatkan dugaan bahwa silika dalam tanah diatomit mempunyai struktur mirip dengan silika gel (silika amorf). Perbedaan utama dari termogram tanah diatomit dengan silika gel terletak pada penunuruan massa pada temperatur $120-580^{\circ} \mathrm{C}$. Hal ini akibat adanya komponen senyawa karbon volatil dalam tanah diatomit yang hilang pada daerah pemanasan tersebut.

$\begin{array}{lrr}\text { Karakterisasi tanah } & \text { diatomit } \\ \text { juga dilakukan } & \begin{array}{r}\text { dengan } \\ \text { spektrofotometer }\end{array} & \text { untuk }\end{array}$
mengidentifikasi gugus-gugus yang ada dalam berbagai jenis tanah, baik sebelum dan sesudah pemanasan. Hasil analisis disajikan dalam Gambar 3 . Dari gambar tersebut nampak beberapa spektra khas dari silika gel amorf. Spektra pada kisaran $3431,1-3448,5$ $\mathrm{cm}^{-1}$ merupakan spektra khas dari vibrasi ulur gugus $-\mathrm{OH}$ dan spektra lemah pada $877,6 \mathrm{~cm}^{-1}$ yang menunjukkan adanya serapan deformasi Si-OH. Spektra serapan kuat pada $1047,3-1058 \mathrm{~cm}^{-1}$ menunjukkan adanya rangkaian $\mathrm{Si}-\mathrm{O}-\mathrm{Si}$, didukung adanya vibrasi rentangan simetris oleh Si-O-Si yang memberikan serapan pada $796,5 \mathrm{~cm}^{-1}$. Spektra kuat pada $468-$ $472 \mathrm{~cm}^{-1}$ menunjukkan adanya vibrasi tekuk $\mathrm{Al} / \mathrm{Si}-\mathrm{O}$.

Perbandingan intensitas secara kualitatif terhadap intensitas setiap spektra khas dari berbagai jenis tanah secara umum menunjukkan bahwa terjadi penurunan serapan pada spektra $-\mathrm{OH}\left(3440 \mathrm{~cm}^{-1}\right)$ dan peningkatan spektra Si-O-Si $\left(1047,3 \mathrm{~cm}^{-1}\right)$ dan Si-O $\left(472,5 \mathrm{~cm}^{-1}\right)$ pada peningkatan temperatur pemanasan. Hal ini sesuai dengan hasil analisis TGA yang menunjukkan bahwa molekul air berkurang pada pemanasan $500^{\circ} \mathrm{C}$ dan menghasilkan siloksan pada temperatur pemanasan mencapai $900^{\circ} \mathrm{C}$. Analisis spektrofotometrilR untuk tanah tanpa pemansan juga dilakukan. Hasil menunjukkan bahwa spektra serapan $\mathrm{OH}$ nampak lebih lemah dibandingkan dengan pada tanah diatoniit setelah pemanasan $300^{\circ} \mathrm{C}$ dan $500^{\circ} \mathrm{C}$. Hal ini dimungkinkan adanya senyawa karbon 
anorganik yang dapat menutup gugus $\mathrm{OH}$ sehingga serapannya tidak nampak tajam. Jika didasarkan pada analisis TGA, pada pemanasan $900^{\circ} \mathrm{C}$ semua gugus silanol telah terkondensasi sempurna sehingga tidak terdapat lagi gugus $\mathrm{OH}$. Walaupun demikian, karena adanya sifat penyerap air dari silika menyebabkan munculnya spektra untuk gugus $\mathrm{OH}$.
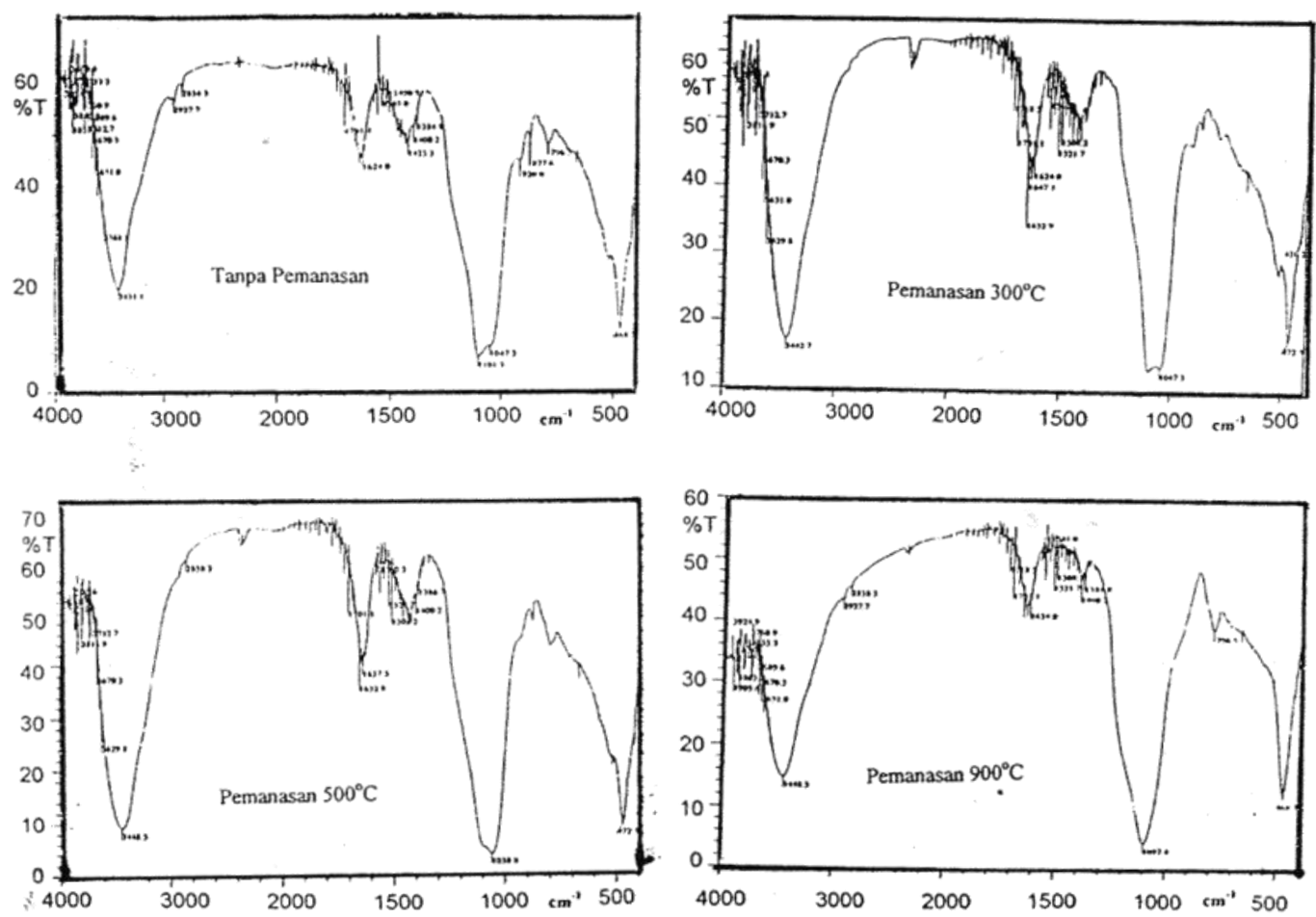

Gambar 3 Spektra spektrofotometri infra merah dari tanah diatomit 


\section{Penetapan Waktu Keseimbangan Adsorpsi}

Waktu keseimbangan dapat ditetapkan melalui kurva hubungan antara jumlah logam yang teradsorpsi dengan waktu kontak. Kurva disajikan dalam Gambar 4. Gambar tersebut di atas menunjukkan bahwa secara umum adsorpsi untuk Cd(II) meningkat lebih tajam daripada $\mathrm{Cr}$ (III) sampai 30 menit, kemudian setelah itu cenderung konstan. Dengan demikian, adsorpsi Cd(II) mencapai keimbangan lebih cepat dibanding dengan adsorpsi $\mathrm{Cr}(\mathrm{III})$. Walaupun demikian, untuk mendapatkan kondisi yang aman maka dinyatakan bahwa keseimbangan adsorpsi kedua jenis ion tercapai setelah kontak berlangsung 60 menit. Waktu optimum ini selanjutnya digunakan untuk semua penelitian berikutnya. Hasil ini sesuai dengan yang diperoleh peneliti pendahulu [6] yang menyatakan bahwa keseimbangan adsorpsi untuk logam $\mathrm{Hg}(\mathrm{II})$ dalam tanah diatomit tercapai pada kisaran 0 2 jam.

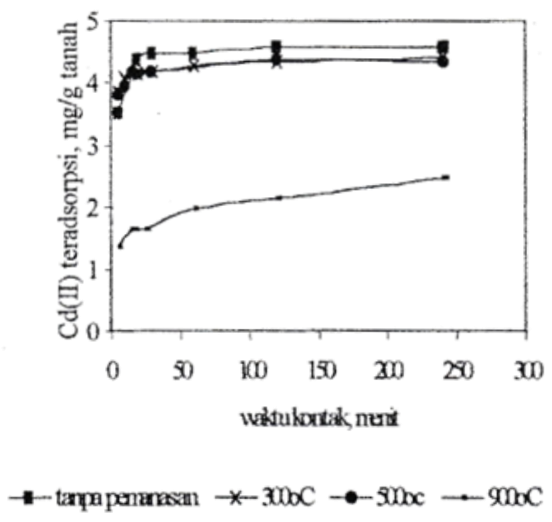

Kecenderungan yang menarik dibahas terjadi pada adsorpsi $\mathrm{Cr}$ (III) oleh tanah yang dipanasi $500^{\circ} \mathrm{C}$ dan $900^{\circ} \mathrm{C}$. Sampai 30 menit, adsorpsi meningkat, tetapi kemudian setelah itu terjadi penurunan dan konstan setelah 60 menit. Gejala ini dimungkinkan akibat terjadinya perubahan struktur tanah selama pemanasan sehingga selama pengadukan terjadi penyusunan kembali struktur tanah, yang memungkinkan terjadinya pelepasan kembali logam yang telah teradsorpsi

\section{Tipe Adsorpsi Isotermal}

Menurut Giles dalam Khan [8], berdasarkan mekanisme adsorpsi, tipe adsoprsi isotermal dapat dibedakan menjadi 4 macam. Secara sederhana, tipe adsorpsi dapat ditetapkan dengan melihat kurva hubungan antara banyaknya logam yang teradsorpsi dengan konsentrasi logam dalam larutan pada saat tercapai keseimbangan. Kurva untuk adsorpsi $\mathrm{Cr}(\mathrm{III})$ dan $\mathrm{Cd}(\mathrm{II})$ disajikan dalam Gambar 5.

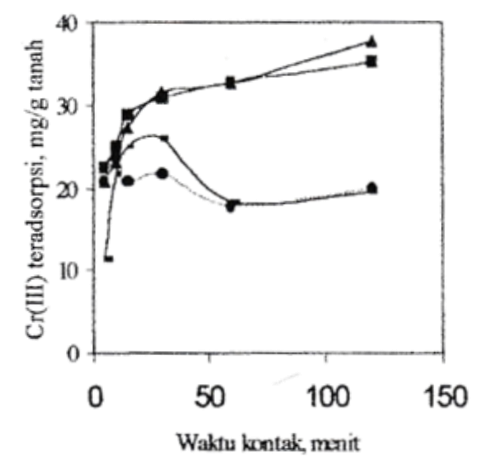

- tampa permanasan $\rightarrow-3000 \mathrm{C} \rightarrow 5000 \mathrm{C} \longrightarrow 9000 \mathrm{C}$

Gambar 4 Kurva hubungan antara jumlah logam teradsorpsi dengan waktu kontak. Kondisi adsorspi: Untuk Cd(II) konsentrasi awal 30 ppm, pH 5.0 - 7.0; untuk $\mathrm{Cr}(\mathrm{III})$ konsentrasi awal $50 \mathrm{pm}$, $\mathrm{pH} 4,0-6,0$ 
Kurva itu diperoleh dari hasil mengkaji pengaruh konsentrasi awal terhadap jumlah logam yang terserap.

Dari kurva dalam gambar di atas terlihat bahwa pada kurva bagian awal kedua jenis logam yang dikaji mempunyai kemiripan kecenderungan, dan perbedaan terletak pada bagian akhir kurva. Berdasarkan klasifikasi yang diusulkan oleh Giles [8] kedua jenis logam cenderung mempunyai tipe adsorpsi L (Langmuir), yaitu tipe yang afinitas adsorpsinya cukup besar pada tahap awal dan terbentuk lapisan ganda. Perbedaan pada akhir kurva karena Cd(II) mempunyai afinitas adsorpsi yang relatif rendah sehingga adsorben lebih cepat mencapai keadaan maksimal. Sebaliknya pada logam $\mathrm{Cr}(\mathrm{III})$ yang mampu teradsorpsi dengan afinitas cukup besar masih berada dalam tahap awal pada kondisi yang dikaji. Perbedaan besarnya afinitas adsorpsi antara $\mathrm{Cr}$ (III) dengan $\mathrm{Cd}(\mathrm{II})$ dapat diterangkan secara sederhana dengan menggunakan teori tarikan elektrostatik. Logam $\mathrm{Cr}$ (III) yang bermuatan +3 dan berukuran lebih kecil mampu berinteraksi lebih banyak

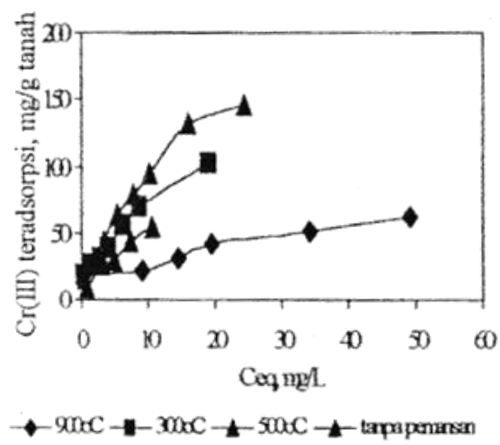

dengan permukaan atau dengan situs aktif dari tanah diatomit (atom oksigen) yang mempunyai muatan parsial negatif. Sebaliknya, ion Cd(II) yang bermuatan lebih rendah dengan ukuran lebih besar sangat selektif terhadap permukaan tanah diatomit, yaitu hanya berinteraksi dengan situs-situs yang betul betul mempunyai kerapatan elektron sangat tinggi, seperti pada gugus silanol.

\section{Kajian Termodinamika Adsorpsi Logam}

Dalam kajian ini dilaporkan beberapa parameter yang mengontrol termodinamika adsorpsi, antara lain tetapan keseimbangan adosrpsi dan energi adorpsi (energi bebas Gibbs). Parameter tersebut ditentukan dengan persamaan yang dikemukakan oleh Langmuir [9].

$$
\frac{c}{m}=\frac{1}{b K}+\frac{1}{b} c
$$

dengan $c$ adalah konsentrasi keseimbangan, $m$ adalah jumlah logam yang teradsorpsi per gram adsorben, $b$ dan $K$ merupakan tetapan, yaitu

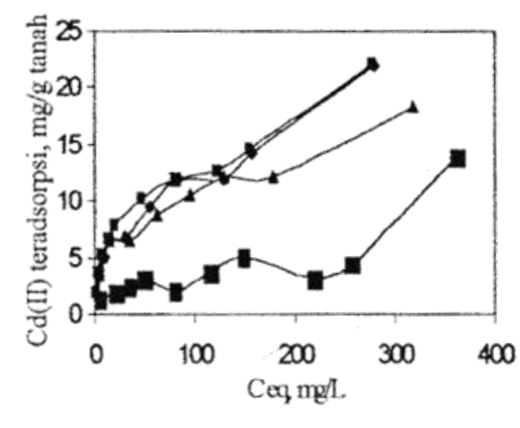

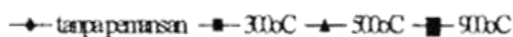

Gambar 5 Kurva hubungan antara banyaknya logam yang terserap dalam tanah diatomit dengan konsentrasi logam setelah mencapai kesetimbangan, $\mathrm{pH}$ 4.0-6.0 untuk $\mathrm{Cr}$ (III) dan pH 5.0-7.0 untuk Cd(II). 
kapasitas adsorpsi dan tetapan keseimbangan adsorpsi. Dari kurva linier hubungan antara $c / m$ versus $c$ dapat ditentukan harga $b$ dari kemiringan, dan $K$ dari intersep kurva. Nilai $c$ dan $m$ diperoleh dari data jumlah logam teradsorpsi pada berbagai konsentrasi awal logam. Dari nilai $K$ yang diperoleh, besarnya energi adsorpsi, $E$, dapat dihitung dengan menggunakan persamaan

$$
E=-\Delta G=R T \ln K
$$

Hasil perhitungan dapat dilihat dalam Tabel I. Dalam tabel itu terlihat bahwa adsorben tanah diatomit mampu mengadsorpsi logam $\mathrm{Cr}$ (III) jauh lebih tinggi daripada $\mathrm{Cd}(\mathrm{II})$ sebagaimana telah dibahas pada bagian awal. Jika dibandingkan kapasitas adsorpsi logam pada berbagai temperatur pemanasan terlihat bahwa untuk logam $\mathrm{Cr}$ (III) adsorpsi cenderung meningkat dengan meningkatnya temperatur pemanasan sampai $500^{\circ} \mathrm{C}$. Kecenderungan ini diduga ada korelasinya dengan keberadaan komponen volatil yang hilang dalam pembakaran. Dalam tanah diatomit alam, kandungan senyawa yang hilang dalam pembakaran mencapai 9,8\% massa, yang diduga berasal dari karbon dan sulfur anorganik [3].Senyawa ini kemungkinan menutupi pori-pori tanah yang merupakan situs aktif terhadap adsorpsi ion $\mathrm{Cr}(\mathrm{III})$. Jika tanah ini dipanaskan maka senyawa tersebut semakin

Tabel I Harga beberapa parameter temodinamika adsorpsi, temperatur $30^{\circ} \mathrm{C}$

a) Logam $\mathrm{Cr}$ (III)

\begin{tabular}{|l|c|c|c|c|}
\hline Perlakuan & Linieritas & $\begin{array}{l}\text { Kapasitas adsorpsi } \\
(b), \mathrm{mg} / \mathrm{g} \text { tanah }\end{array}$ & $\begin{array}{l}\text { Tetapan } \\
\text { keseimbangan, } \\
\text { adsorpsi, } K\end{array}$ & $\begin{array}{l}E, \\
\mathrm{~kJ} / \mathrm{mol}\end{array}$ \\
\hline $\begin{array}{l}\text { Tanpa } \\
\text { pemanasan }\end{array}$ & 0,9837 & 103,06 & $1,58 \times 10^{3}$ & 18,55 \\
\hline $\begin{array}{l}\text { Pemanasan } \\
300^{\circ} \mathrm{C}\end{array}$ & 0,9302 & 148,00 & $1,08 \times 10^{3}$ & 17,60 \\
\hline $\begin{array}{l}\text { Pemansan } \\
500^{\circ} \mathrm{C}\end{array}$ & 0,9153 & 205,33 & $0,96 \times 10^{3}$ & 17,30 \\
\hline $\begin{array}{l}\text { Pemansan } \\
900^{\circ} \mathrm{C}\end{array}$ & 0,9766 & $77,03$. & $1,48 \times 10^{3}$ & 18,39 \\
\hline
\end{tabular}

b) Logam Cd(II)

\begin{tabular}{|l|c|c|c|c|}
\hline Perlakuan & Linieritas & $\begin{array}{l}\text { Kapasitas adsorpsi } \\
(b), \mathrm{mg} / \mathrm{g} \text { tanah }\end{array}$ & $\begin{array}{l}\text { Tetapan } \\
\text { keseimbangan, } \\
\text { adsorpsi, } K\end{array}$ & $\begin{array}{l}E, \\
\mathrm{~kJ} / \mathrm{mol}\end{array}$ \\
\hline $\begin{array}{l}\text { Tanpa } \\
\text { pemanasan }\end{array}$ & 0,9951 & 13,51 & $6,93 \times 10^{3}$ & 22.28 \\
\hline $\begin{array}{l}\text { Pemanasan } \\
300^{\circ} \mathrm{C}\end{array}$ & 0,9866 & 14,93 & $7,74 \times 10^{3}$ & 22,56 \\
\hline $\begin{array}{l}\text { Pemansan } \\
500^{\circ} \mathrm{C}\end{array}$ & 0,9805 & 13,49 & $5,07 \times 10^{3}$ & 21,49 \\
\hline $\begin{array}{l}\text { Pemansan } \\
900^{\circ} \mathrm{C}\end{array}$ & 0,9899 & 3,63 & $11,51 \times 10^{3}$ & 23,56 \\
\hline
\end{tabular}


berkurang dan hilang sempurna pada pemanasan sampai $580^{\circ} \mathrm{C}$, yang berakibat makin terbukanya situs-situs aktif itu. Dengan demikian, kemampuan mengadsorpsi ion $\mathrm{Cr}(\mathrm{III})$ meningkat. Sebaliknya, pada pemanasan $900^{\circ} \mathrm{C}$, terjadi penuruan kapasitas adsorpsi. Hal ini dapat dipahami akibat hilangnya gugus silanol yang diduga juga memberi sumbangan dalam adpsorpsi terhadap ion logam. Sebagaimana hasil yang diperoleh dari analisis termogravimetri bahwa pada temperatur itu silanol telah berubah sempurna menjadi siloksan. Dari hasil ini dapat diduga bahwa adsorpsi $\mathrm{Cr}$ (III) cenderung dominan untuk adsorpsi secara fisik. Meskipun ion $\mathrm{Cr}(\mathrm{III})$ bermuatan positif tinggi dan berukuran kecil (jejari 75,5 pm) nampaknya tidak membuat interaksi dengan gugus aktif tanah diatomit menjadi lebih kuat. Hal ini akibat terbentuknya kompleks akuo dari Cr(III) yang stabil sehingga mengurangi kekuatan berinterasi secara kimia dengan situs aktif dari tanah diatomit. Dengan demikian, adsorpsi ion $\mathrm{Cr}(\mathrm{III})$ terjadi karena interaksi atau ikatan hidrogen antara molekul air terkomplekan dengan atom oksigen dalam tanah diatomit, baik dalam silanol maupun siloksan.

Kecenderungan pengaruh temperatur untuk $\mathrm{Cr}(\mathrm{III})$ berbeda dengan untuk $\mathrm{Cd}(\mathrm{II})$. Seperti terlihat dalam Tabel $\mathrm{I} b$., pemanasan sampai $500^{\circ} \mathrm{C}$ kapasitas adsorpsi tidak berubah secara signifikan. Hal ini diduga adsorpsi logam $\mathrm{Cd}(\mathrm{II})$ tidak sangat dipengaruhi oleh pori-pori adsorben, tetapi lebih bergantung pada banyaknya gugus silanol tanah. Pemanasan sampai $500^{\circ} \mathrm{C}$, gugus silanol belum terkondensasi, sehingga kemampuan mengadsorpsi $\mathrm{Cd}$ (II) juga tidak terlalu berubah. Selanjutnya pemanasan $900^{\circ} \mathrm{C}$ telah mengkondensasi sempurna gugus silanol sehingga kemampuan tanah diatomit mengadsorpsi Cd(II) menurun secara nyata. Dari hasil ini dapat pula diperkirakan bahwa logam $\mathrm{Cd}(\mathrm{II})$ cenderung teradsorpsi secara kimia dengan interaksi antara $\mathrm{Cd}(\mathrm{II})$ dengan atom oksigen dalam gugus silanol. Ukuran ion $\mathrm{Cd}(\mathrm{II})$ yang relatif lebih besar (jejari 109 pm) dan muatan rendah mengakibatkan kurang mampu memasuki pori-pori yang kecil, sehingga dimungkinkan interaksi antara ion dan situs aktif (gugus silanol) hanya terjadi secara kimia pada bagian antar muka.

Dugaan adsorpsi secara kimia untuk Cd(II) dan secara fisik untuk $\mathrm{Cr}$ (III) didukung oleh kurva hubungan antara banyaknya logam teradsorpsi dengan konsentrasi dalam kesimbangan (Gambar 4) dan besarnya energi adsorpsi. Gambar 4 menunjukkan bahwa pada daerah konsentrasi keseimbangan rendah, peningkatan konsentrasi . keseimbangan menyebabkan peningkatan yang tajam dari jumlah logam teradsorpsi. Selanjutnya peningkatan konsenstrasi lebih lanjut, jumlah logam teradsorpsi cenderung konstan. Pola kurva semacam ini sesuai dengan mekanisme adsorpsi melalui interaksi kimia menurut Langmuir. Berbeda dengan $\mathrm{Cd}(\mathrm{II})$, adsorpsi logam $\mathrm{Cr}(\mathrm{III})$ mempunyai pola adsorpsi fisik, yaitu kenaikan konsentrasi keseimbangan dikuti oleh kenaikan jumlah logam teradsorpsi secara lamban.

Ditinjau dari segi energi adsorpsi (Tabel I), terlihat bahwa energi adsorpsi logam Cd(II) relatif lebih besar daripada logam $\mathrm{Cr}(\mathrm{III})$. Sebagaimana dikemukakan oleh Oscik [10] bahwa adsorpsi kimia mempunyai energi lebih besar dibandingkan adsorpsi fisika, dengan batas energi 20 
$\mathrm{kJ} / \mathrm{mol}$. Dengan demikian berdasarkan besarnya energi adsorpsi dapat dikatakan bahwa interaksi yang mendominasi adsorpsi logam $\mathrm{Cr}(\mathrm{II})$ dalam tanah diatomit adalah interaksi fisik, sedangkan adsorpsi ion $\mathrm{Cd}(\mathrm{II})$ cenderung secara kimia.

\section{KESIMPULAN}

Dari hasil penelitian ini dapat disimpulkan bahwa perlakukan pemanasan pada temperatur sampai $500^{\circ} \mathrm{C}$ tidak menurunkan kemampuan tanah diatomit untuk mengadsorpsi logam $\mathrm{Cr}$ (III) dan $\mathrm{Cd}(\mathrm{II})$. Penurunan secara tajam (2 - 4 kali) terjadi pada pemanasan temperatur $900^{\circ} \mathrm{C}$, setelah terjadi kondensasi gugus silanol menjadi siloksan. Berdasarkan besarnya energi, adsorpsi logam $\mathrm{Cr}$ (III) dalam tanah diatomit pada berbagai perlakukan menunjukkan akibat terjadinya interaksi fisik, yaitu ikatan hidrogen antara hidrogen dalam kompleks akuo dengan atom oksigen dalam tanah, sedangkan adsorpsi $\mathrm{Cd}$ (II) terjadi karena adanya ikatan kimia antara ion $\mathrm{Cd}(\mathrm{II})$ dengan gugus silanol dalam tanah.

\section{UCAPAN TERIMA KASIH}

Penulis mengucapkan banyak terima kasih kepada Y. Irawati dan J.H. Saragih yang telah membantu dalam pengumpulan data penelitian.

\section{DAFTAR PUSTAKA}

1. Semu, E., Singh, B.R., dan SelmerOslen, A.R., 1987, "Adsorption of Mercury Compounds by Tropical Soils: III. Adsorption Isoterm", Water, Air, and Soil Pollut., 32, 1116

2. Saadi, P., 1995, "Kajian tentang Pemanfaatan Gambut sebagai Adsorben Senyawa Merkuri(II) Anorganik dari Larutan", Tesis S-2, UGM, Yogyakarta
3. Mahdian, 1997, "Studi tentang Adsorpsi Desorpsi Ni(II), Co(II), dan Mn(II) dalam Medium Air pada Adsorben Tanah Diatomeae Sangiran Sragen, Jawa Tengah", Tesis S-2, Pascasarjana, UGM, Yogyakarta

4. Barron, J.A., 1987, Diatomite: Enviromental and Geologic Factors Affecting Its Distribution, dalam J.R. Hein (edt.), " Siliceous Sedimentary Rock-Hosted Ores and Petroleum" Van Nostrand Reindhold, New York.

5. Priatna, K., Nugraha, Y., Rukiah, 1990, “ Studi Pendahuluan Kemungkinan Pemanfaatan Diatome asal Solo sebagai Adsorbat Air Nira" Bulletin PPTM, 12, 7-22

6. Purwanto A., dan Narsito, 1998, "Impregnasi 2-Merkaptobenzotiazol pada Tanah Diatomeae dan Pemanfaatannya sebagai Adsorben Raksa(II) dalam Medium Air" J. Pascasarjana, UGM, proses terbit

7. Scott, RP.W., 1993, Silica Gel and Bonded Phases: Their Production Properties and Use in Liquid Chromatography, John Wiley and Sond, Chichester.

8. Khan, S.U., 1980, Pesticides in the Soil Enviroment, Elsevier Scientific Publishing Company, Amsterdam.

9. Adamson, A.W., 1990, Physical Chemistry of Surface, $5^{\text {th }}$ ed., John Wiley and Sons, New York

10. Oscik, J., 1982, Adsorpstion, John Wiley and Sons, Chichester.

11. Filho, N.L.D., Gushikem, Y., dan Polito, W.L., 1995, "2Mercaptobenzothiazole clay as Matrix for Sorption and Preconcentration of Some Heavy Metals from Aqueous Solution", Anal. Chim. Acta, 306, 167-172. 